\title{
Tomasz Gałkowski CP, Ogólne zasady prawa w prawie kanonicznym \\ [General Principles of Law in the Canon Law] Warszawa: Wydawnictwo Naukowe Uniwersytetu Kardynała Stefana Wyszyńskiego, 2020, $221 \mathrm{pp}$.
}

The well-known Polish canonist, head of the Department of the Theory of Church Law in the Faculty of Canon Law of the Cardinal Stefan Wyszyński University in Warsaw, created a monograph, which, even though written in Polish (with all the restrictions connected with it), has a chance to trigger a broader interest beyond the circle of its natural addresses: lawyers that focus on the theory and praxis of law. Three chapters, well-edited within the substantive and formal plain, preceded by the means of an Introduction and concluded not only by the means of a standard Conclusion, as well as Deductions closing the consecutive research stages - yield a holistic and cohesive image of these issues. What should be immediately emphasized is the fact that it concerns an issue, which anyone familiar with the heritage of the European legal culture, and even more a lawyer-canonist who understands the system specificity: ordo Caritatis-Ecclesia iuris, recognizes as fundamental. The author, distant from-not infrequently (unfortunately!) encountered in canon law literature eclectic depictions of "general rules of law" (here, obviously, we should not confuse the lack of respecting the autonomy of systems marked by the state leges and church canones in the affirmation of much desired creative dialog of legal cultures), from time to time shifts the emphasis of the discourse towards the last part of the title: "[...] in the canon law." The technique is both original and methodologically apt, since the only thing we can do is to applaud such thought-out and consistently 
implemented hermeneutical circle figure. The author explains: "The existing legal system is a basis for understanding the principles, which contributed to its creation and which should be located in the normative solutions included therein. They reflect the preferences, constitute criteria, which explain the choices made by the legislator and are a basis of the coherence between the regulations of law" (p. 103). The established perspectives of contextual contemplation of the title "principles" are: (1) Code of Canon Law (nota bene the lack of the Code of Canons of the Eastern Churches in author's analysis was not appropriately justified, for example, in pointing direction towards the existence of strict/based on necessity relation between law and the Community; the negligible remark in reference 29 (pp. 27-28) does not compensate for it), (2) theory of canon law, (3) theology of canon law. The author reveals, in these three scenes, the program (!) favoring of "historical and redemptive orientation of practicing the study of canon law" (p. 14). The characteristic sign of such positioning is the repeatedly quoted thought suggesting that an adequate cognitive horizon, on which generalia iuris principia should be situated, is the theological context of ius Ecclesiae. Consequently, their meanings in the canon law system cannot be brought down to merely the function of a tool solving legislative loopholes (the author justly emphasizes the insufficiency of theoretical and legal depictions that would refer to the common legal culture heritage and analogous functioning of the title principles in the canon and state legal systems). That is how a proper, accurately determined, space of subject contemplation is opened. The central place in the monograph belongs to the following supposition: since it is true that the "positive law system is not the only source of Church law" (p. 147), then the main reference point in the proper exegesis and application of can. 19/CIC 1983 should be the two paradigmatic theses: (1) lex canonica should be understood as ordinatio fidei, (2) the elementary criterion in complementing law (determining a specific case and confirming law_-understand: acknowledging the existence of subjective rights/duties of a believer - in the face of the lack of an explicit general or particular act, or common law) is a hermeneutical triad: salus animarum-aequitas canonica-generalia iuris principia. We can boldly say that it is owing to these assumptions that the author managed to credibly present the clou of the specific nature of Church law and realize the planned research goal. What seals it is the central positioning in the determination of the title issue of the "canonical equity" institution, the role of which is not brought down by the author merely to filling legislative loopholes. Indeed, it was necessary to draw conclusions from the fact that aequitas canonica constitutes par excellence the internal and formal impetus for justice and dynamic principle of creation and development of law. The author's statement addresses the issue: "The aim of canonical equity [...] is to correct every situation where there is a risk of rigor iuris. The function of canonical equity is to complement law, which, as a result, leads to its rule-making function and correcting law where it is defective" 
(pp. 147-148). In conclusion, I personally see the main value of the reviewed item in the indication towards generalia iuris principia as a tool of mitigating the harmful antinomy mostly between: formal and material justice, what is public (bonum communel bonum communionis) and what is private (bonum personae). At the end of the day it is about the principles that convey the potential of supporting - system in ius Ecclesiae_- "alliance" of law and ministry (see John Paul II's famous address to the Roman Rota from 1990), directed towards real protection/promotion of subjective rights of the faithful in the Church, in the name of the realization of the salus animarum goal. 